\title{
The Bohemian Brethren and the Protestant Reformation ${ }^{\dagger}$
}

\author{
Craig Atwood
}

check for

updates

Citation: Atwood, Craig. 2021. The Bohemian Brethren and the Protestant Reformation. Religions 12: 360. https://doi.org/10.3390/rel12050360

Academic Editors: Thomas A. Fudge and Marina Montesano

Received: 4 March 2021

Accepted: 27 April 2021

Published: 19 May 2021

Publisher's Note: MDPI stays neutral with regard to jurisdictional claims in published maps and institutional affiliations.

Copyright: (C) 2021 by the author. Licensee MDPI, Basel, Switzerland. This article is an open access article distributed under the terms and conditions of the Creative Commons Attribution (CC BY) license (https:/ / creativecommons.org/licenses/by/ $4.0 /)$.
Theology Department, Moravian University, Bethlehem, PA 18018, USA; atwoodc@moravian.edu † This article is built upon my book Theology of the Czech Brethren from Hus to Comenius (State College, PA: University of Pennsylvania Press, 2009).

\begin{abstract}
The smallest, but in some ways the most influential, church to emerge from the Hussite Reformation was the Unity of the Brethren founded by Gregory the Patriarch in 1457. The Unity was a voluntary church that separated entirely from the established churches, and chose its own priests, published the first Protestant hymnal and catechism, and operated several schools. Soon after Martin Luther broke with Rome, the Brethren established cordial relations with Wittenberg and introduced their irenic and ecumenical theology to the Protestant Reformation. Over time, they gravitated more toward the Reformed tradition, and influenced Martin Bucer's views on confirmation, church discipline, and the Eucharist. In many ways, the pacifist Brethren offered a middle way between the Magisterial Reformation and the Radical Reformation. Study of the Brethren complicates and enhances our understanding of the Protestant Reformation and the rise of religious toleration in Europe.
\end{abstract}

Keywords: Brethren; Bohemian; Moravian; Luke of Prague; Michael Weisse; Martin Bucer; humanism; Utraquist; sacraments; Gregory the Patriarch; Poland; Martin Luther; catechism; Eucharist; pacifism; oaths; sermon

\section{Introduction}

Jan Hus was burned at the Council of Constance in 1415 as a heresiarch, and his followers in Bohemia and Moravia, especially the Bohemian Brethren, were condemned as schismatics teaching dangerous doctrines. Prior to the posting of the Ninety-five Theses, Martin Luther, like most doctors of theology, viewed the Hussites as heretics to be avoided. He wrote:

When I was a papist, I truly and cordially hated these Pickard ${ }^{1}$ Brethren with great zeal toward God and religion and without any aim of gaining money or glory. When I came upon some books of John Hus unawares one time and saw that the Scriptures were treated so powerfully and purely that I began to wonder why the pope and council had burned such a great man, I immediately closed the book in terror, suspecting that there was poison hidden under the honey by which my simplicity might be infected; such a violent fascination with the name of the pope and council ruled over me. (Pelikan and Hotchkiss 2003, p. 799)

Luther's opinion of Hus changed in 1519 during the Leipzig debate over the doctrine of indulgences. At a tense moment in the debate in Leipzig, John Eck openly accused Luther of being a Hussite because of his rejection of the pope's authority to declare dogma, specifically the dogma of indulgences. During a recess, Luther read an account of the Council of Constance that included Hus's defense of his writings. When the debate resumed, Luther shocked both his opponents and supporters by declaring: "Among the articles of John Hus, I find many which are plainly Christian and evangelical, which the universal Church cannot condemn." (Bainton 1978, p. 89). People began calling Luther the "Saxon Hus" either in praise or blame and soon woodcuts depicted him and Hus serving both the bread and wine to laity in Hussite fashion (Haberkern 2016, 2017). Luther 
was sometimes depicted as a swan alongside the goose (Hus) in Protestant propaganda (Scribner 1986, pp. 41-42).

Soon after the Leipzig debate, Luther and Philip Melanchthon established cordial relations with the Utraquist Church and the Bohemian Brethren (also known as the Unity of the Brethren. ${ }^{2}$ The Unity of the Brethren was a small pacifist Hussite church that formally separated from the Utraquist Church in 1467 when it established its own priesthood and episcopacy. In many ways, the Brethren followed the teachings of the Church of Tábor, but repudiated violence. ${ }^{3}$ Thanks primarily to Luther's efforts, the Bohemian Brethren became part of the so-called Magisterial Reformation while maintaining some of the distinctive features of the Czech Reformation. This paper will examine the relationship of the Bohemian Brethren to the Protestant Reformation, showing ways the Brethren both contributed to Protestant practice and adapted to Protestantism. There has been a resurgence of interest in the Czech Reformation since the Velvet Revolution of 1989, but most of the research has focused on Jan Hus and the early Hussite movement. ${ }^{4}$ There has been less attention given to the history of the Bohemian Brethren, in part because the church was destroyed in the 17th century. The Czech Reformation in general, and the Brethren in particular, have often been dismissed as a failure and their contributions to European religious and social history overlooked (Haberkern 2018). We will begin with a brief look at the history of the Brethren and their religious practices prior to contact with Luther. ${ }^{5}$

\section{Part 1-The Brethren before the Reformation}

\subsection{The Unity of the Brethren}

The Unity of the Brethren (also known as the Bohemian Brethren) was established in eastern Bohemia sometime in 1457 or 1458 (Halama 2020, pp. 371-402; Crews 2008; Říčan 1992; Müller 1922). The founder of the Unity was a young man named Gregory (called the Patriarch by his followers) whose uncle, Jan Rokycana, was the leader of the Utraquist Church and an advisor of the Hussite king of Bohemia, George Poděbrady (Odložilîk 1965; Kalivoda 2014, pp. 43-62). Gregory grew up admiring Hus as a saint and martyr, but he felt that the Utraquist Church had not fully reformed religious and moral life in Bohemia. Gregory admired the theology of the radical Hussite sect called the Church of Tábor, but he was appalled by the apocalyptic violence of the Táborites that had devastated many places in Bohemia and surrounding areas. While working as the business manager of a Hussite monastery in Prague, Gregory read the works of one of the most original and radical thinkers of the Middle Ages, a Bohemian layman named Peter Chelčický (c. 1380-c. 1458, Peschke 1981, p. 81). According to Matthew Spinka, Chelčický's "unyielding and unequivocal insistence on the separation of church and state, and to a somewhat less degree his pacifism, raised him to the rank of a pioneer of future types of Christianity." (Spinka 1943, p. 271).

As a young man, Chelčický had heard Hus preach in southern Bohemia and joined in the ferment in Prague following Hus's execution. Although he had little formal education, he was well read in theology and the Bible, and he was able to discuss Christian doctrine with the University masters in Prague. Chelčický quickly grew frustrated with the conservativism of the Utraquists, especially their continuing efforts to be reconciled to Rome, so he left Prague and returned to Chelčice where he remained until his death. He wrote several seminal works in Czech, most notably The Net of Faith, that were critical of Catholics, Utraquists, and Táborites alike. ${ }^{6}$

In a 1440s work titled Reply to Rokycana, Chelčický acknowledged both his admiration for and distance from the mainstream of the Czech Reformation. "And this much I say of them [Hus, Matthew, Jakoubek], not abusing their good works that they have done in the name of God by zealous preaching and other good things. But I will further say, they too have drunk of the wine of the Great Whore, with which she has besotted all the nations and the people ... For they have written things in their works which are denied by the divine laws, especially where Master Hus has written of murder, the oath, and images."7 Chelčický argued that the Utraquists' claim to have reformed the church in Bohemia was 
hypocrisy since they embraced the same alliance of church and state that was the source of corruption in the Roman Church (Iwánczak 1997, pp. 271-83). He held to the Waldensian view that the conversion of Constantine had caused the fall of the Catholic Church, and a true reformation of Christianity must abolish the alliance of church and state. He also insisted the New Testament alone provides a description of the true church living under the Law of Christ (Wagner 1983, pp. 83-89). Chelčický remained on fairly good terms with the Táborites, with whom he had much in common theologically, despite his condemnation of their religious-based violence. He insisted that the devil was using the Old Testament to seduce the Táborites into embracing the ideology of crusade. For Chelčický, one of the marks of true Christianity is pacifism. Since the true church must model Christian virtues, it can never participate in the violence and injustice of the secular world. Christians should pay their taxes (Romans 13), but they should never shed blood or swear oaths, even at the cost of their own lives. Chelčický not only rejected the Catholic Church, he declared that the whole feudal order with its sanctified violence belonged to the antichrist. The true church belonged to Christ (Wagner 1983, p. 149).

Chelčický argued that the medieval idea of three estates (nobility, clergy, commoners) was contrary to the teachings of both Jesus and the Apostle Paul and thus has no place in the body of Christ (I Cor. 12: 21-26).

The triply divided Christian people, carnal and full of dissension, neither can nor ever will have that unity and love of one another; it is the world, and it has in itself only worldly desires. Therefore, it cannot rightly be said that the Body of Christ is composed in that triple form, for even among the pagans there is such a division of the people into three parts. (Chelčický 1964, p. 156)

Unlike university-trained reformers like Hus, Luther, and Calvin, Chelčický's rejection of papal authority was a rejection of the notion of Christendom itself. He argued that the early church had no pope, no king, no lords, no tithes, no inquisition, no crusades, and no pretense of being part of pagan society. It was a community of mutual love where each was brother and sister and the only Lord was Christ. The solution to corruption in the church is to remove the secular power and wealth of the church (Chelčický 1964, p. 173). The apostle Paul in I Corinthians (12: 25-26) "requires undivided equality among the limbs of the body, so that without envy they serve each other, take care of each other, share everything with each other-if the good, they rejoice together; if the bad, they suffer together." (Chelčický 1964, p. 172).

Chelčický drew upon the Waldensian idea of there being six smaller (or stricter) commandments of Christ found in the Sermon on the Mount: do not respond to violence with violence, do not divorce your spouse, do not swear oaths, do not be angry without cause, do not look lustfully at someone, and love your enemies. ${ }^{8}$ In many ways, Chelčický anticipated many principles of the 16th century Anabaptists although he accepted the validity of infant baptism and retained his belief in transubstantiation (Wagner 1983, p. 114). Chelčickýs opposition to the oath was closely connected to his pacifism. By refusing to swear oaths, the disciples of Christ could not serve in the military, stand in judgment of others in trials, or participate in many guilds. The church of the true disciples of the Law of Christ should withdraw from pomp, hypocrisy, deception, and violence.

Gregory and a circle of friends in Prague diligently studied Chelčický's main works, especially Net of Faith, and decided that he alone gave the true interpretation of Scripture (Müller 1922, pp. 68-70; Říčan 1992, p. 26). Initially, Gregory's circle was similar to an 18th century Pietist conventicle, but gradually Gregory became convinced that they must separate completely from the evil of the world (Brock 1957, p. 84). With the help of his uncle, Rokycana, Gregory received permission from the king to establish a small community near the village of Kunvald early in 1457 or 1458 (shortly after the death of Chelčický, Müller 1922, p. 70; Řičan 1992, p. 27). They called themselves "Brothers of the Law of Christ" and articulated their foundational theological ideas thus: "Before all things we have first agreed that we will care for one another together in the faith of the Lord Jesus, be established in the righteousness which comes from God, and abiding in love, have hope 
in the living God." (Říčan 1992, p. 34). Gregory traveled extensively seeking converts, especially among people with ties to the Waldensians, Táborites, Beghards, Free Spirits, and Pikards in Bohemia and Moravia. The Brethren also attracted a few dissident Utraquist and Catholic priests. ${ }^{9}$

The first persecution of the Brethren took place in 1461. The Brethren repeatedly called for their enemies to recognize that religious persecution is itself sinful. Rather than protecting the truth or spreading the gospel of Jesus Christ, persecution actually destroys the Christian faith because "Christ is opposed to all force; whoever comes to him must do so from a free will." (Müller 1922, p. 86). In other words, faith must be freely given or it is not faith. The nobility should neither use the sword to defend the faith nor to punish heretics, and the clergy should never give their "Amen" to religious violence. Christ did not come to kill, they said, but to make alive. The fact that the Israelites used the sword to defend the law of God merely confirmed for the Brethren that the Old Testament was imperfect and not binding on Christians-unlike the New Testament (Müller 1922, pp. 96, 99).

At the Synod of Rýchnov in 1464, the Brethren formally organized themselves into a pacifist jednota or Unity. They agreed that they would not pay attention to "writings that contradicted divine law, but would content ourselves with the holy Scripture and govern ourselves according to divine law. What was derived from the divine law, we would recognize and judge as good, but what was not derived from divine law, we would judge as doubtful." (Müller 1922, p. 74). It was not theoretical knowledge or doctrine that made a Christian, but the practical transformation of one's life according to the image of Christ (Peschke 1981, pp. 84-85). Gregory described the Brethren as "people who have decided once and for all to be guided only by the gospel and example of our Lord Jesus Christ and his holy apostles in gentleness, humility, patience, and love for our enemies. By this we may do good to our enemies, wish them well, and pray for them." (Říčan 1992, p. 30).

Like Hus and most Catholic theologians, the Brethren taught that humans are saved by faith completed in love. This was the medieval doctrine fides caritate formata and must be distinguished from the Protestant principle of justification by faith. Redemption changes how one treats other human beings. Redemption moves people from violence, greed, and intimidation to generosity, humility, and peacefulness. Love of God included a rejection of worldly delights and willing obedience to the Law of Christ revealed in the Sermon on the Mount. Christ's law was evidenced most dramatically in the ability to love one's enemies. The Unity promoted Augustine's understanding that grace is the work of the Holy Spirit that allows sinful humans to understand what God requires of them, recognize their own imperfection, and grow into the type of person that God expects them to be (Fousek 1961, p. 401). Unlike Luther in the 16th century, the Bohemian Brethren were not looking for freedom from the law; they wanted a stricter discipline than provided in the state church. "The Brethren's connecting a justified hope of salvation with the presence of church discipline in a community shows that they thought of the discipline as being primarily an instrument of the saving activity of God, as a means of grace." (Fousek 1961, p. 397). Church discipline was intended to bring about repentance rather than to punish the sinner. It should be administered in a spirit of mutual love.

In order to facilitate the work of discipline and growth in faith, love, and hope, the Unity divided their membership into four categories: Perfect, Progressing, Beginners, and Penitent. Though much criticized by both Catholics and Protestants, these categories were adopted from the early Christian church (Müller 1922, pp. 108-9; Atwood 2009, pp. 163-67). This system of membership, with minor revisions, remained in place throughout the history of the Unity. By 1600, the categories of membership were called those Beginning, those Proceeding, and those aspiring to Perfection, to reduce the risk of pride and not to offend other Protestants. The Perfect were those who had shown they were mature in faith, love, and hope, were eager to correct their failings, and were free from mortal or deadly sins, such as murder and adultery (Fousek 1971, p. 217). The perfect should also be willing to suffer "hunger and cold, pain, imprisonment and death" for the sake of Christ, just like the early Christian martyrs (Müller 1922, p. 104). Most members were in the Progressing 
category. They were expected to live according to a strict discipline that even stipulated what were legitimate trades and professions. Initially this group was composed of separate groups: one for the married householders and the other for single brothers and sisters. They had separate sets of instructions to guide them in proper Christian living according to their estate. Each home should be a model of a true Christian community where faith, love, and hope rather than violence reigned.

After 1478, the Brethren began baptizing children of members with the understanding that their parents and baptismal sponsors would see to their religious instruction and discipline. Baptized children were classified as Beginners. Around age twelve they received a long period of catechetical instruction that included instruction in the discipline of the Unity. Then they "completed" their baptism through the rite of confirmation. This was called being "received into obedience." Confirmation included a long and probing interview to determine the worthiness of the confirmand. After laying-on of hands and prayer by the priest, the newly confirmed person became a Progressing member and was admitted to communion. Adults who joined the Unity from another church were also Beginners until they completed a process similar to confirmation. First, they made a solemn vow to submit to the authority and pastoral care of the priest and were "received into the obedience of the Unitas." Next was "admission to the Word of God," or to the preaching service. When the priest determined that candidates understood the nature of the Unity, knew what was required of members, and showed promise of being able to live according to the discipline, they could be admitted to the sacraments and counted among those Progressing (Fousek 1971, p. 214).

As early as 1467 , the Brethren decided to establish their own priesthood completely separate from the Utraquists and Catholics because of ongoing persecution (Peschke 1981, pp. 92-95). In the first half of the 15th century, the Hussite reformer Peter Payne, who was known to Gregory, urged the Utraquist Church to establish its own episcopacy rather than relying on ordination from the Catholic Church. The Utraquists rejected Payne's arguments, and went to extraordinary lengths to have their priests ordained by Catholic bishops (David 2003, pp. 143-50). However, Gregory decided that Payne was correct in his understanding that bishops in the New Testament were not fundamentally different from priests. The ordination of a bishop was an act of the community of faith, rather than an act of the bishops themselves (Říčan 1992, p. 37; Peschke 1981, p. 97). Gregory also argued that "all true Christians were spiritual priests. God called some believers to exercise the office of a priest, and this was made evident by his bestowing on them the personal gifts necessary for their spiritual function." (Říčan 1992, p. 36). This anticipated Luther's understanding of the "priesthood of all believers," but the Brethren did not object to the word "priest" as the later Protestants would. The Unity always insisted that the true high priest of the church is Jesus Christ himself; therefore, every priest must strive to follow the example and teachings of Christ (Müller 1922, pp. 114-17). Other than the Church of England, the Unity of the Brethren was the only Protestant Church during the Reformation era that maintained the traditional three orders of ministry: bishop, priest, and deacon.

The first priests and bishop of the Unity were selected at the synod of Lhotka in 1467. Nine candidates chose lots to see who Christ wanted to be priests. The lot fell on three: a farmer, a miller, and a tailor. One of them, Matthew of Kunvald, was chosen as the Senior (bishop) and confirmed by lot (Říčan 1992, pp. 38-39; Müller 1922, pp. 126-27). This appears to be the only time the lot was used by the Bohemian Brethren. Despite repeated criticism from Lutheran and Reformed leaders in the 16th century, the Unity maintained clerical celibacy (except for those married before ordination) until the late 1500s. Michael, who had been ordained a Catholic priest before joining the Unity, consecrated Matthew as Senior. Matthew also received the laying-on of hands from an unnamed Waldense elder as an additional ordination. Then, to complete the circle, Matthew re-ordained Michael as a priest of the Unity after he was confirmed by the lot. ${ }^{10}$ One of the early histories of the Unity reported that all "were bound to obedience to Brother Matthew as bishop similar to the way the Roman church is bound to the Pope, for he was held in great respect by all in 


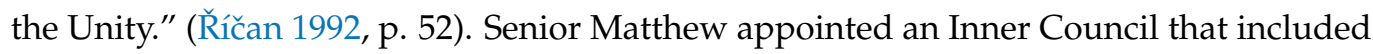
priests and lay persons to give advice and help implement decisions. One of Gregory's arguments against papal supremacy was that even the apostles did not have a monarchal episcopacy. Like Hus, Gregory argued in favor of the early church's arrangement of five patriarchs rather than a single pope; thus, the Brethren adopted a conciliar system of authority (Peschke 1981, pp. 89-91). Priests in the Unity were assisted in their pastoral duties by deacons who were basically priests in training. They were usually young, single men, who lived in the priest's household. They assisted in household duties, and the priest saw to their education and training. Priests also had lay assistants in the congregations. Those who helped administer discipline and settle disputes between members (or between members and the priest) were called judges. Others were almoners who managed the finances of the congregation and saw to the needs of poorer members (Říčan 1992, p. 51).

\subsection{The New Brethren}

The first generation of the Brethren followed an almost monastic discipline and strict pacifism. The Perfect were expected to renounce wealth and live in celibacy and simplicity. All the Brethren were expected to separate from the sinful world, but this was difficult for those living in urban areas, especially Brethren who had moved to the new city of Litomyšl where the local lord protected the Brethren but also expected them to assume civic duties. Some members of the Inner Council were also concerned that their strict discipline was making some Brethren self-righteous and uncharitable. In response to a request from the congregation at Litomyšl, and at the urging of the Council, Senior Matthew called for a synod of the priests, deacons, and congregational helpers to meet at Brandýs in 1490. As a group, they discussed how far a brother may go in exercising power, both passive and active, under a governing authority. Did the Lord forbid the saying of oaths so completely that a person may never swear under any circumstance? (Müller 1922, p. 243). What emerged at the synod was a consensus that the Brethren should be allowed to use secular power so long as they avoided situations where they might be forced to contribute actively or passively to the death of another person. The synod also decreed that it could be possible for some people, with God's help, to maintain a clear conscience in fulfilling their civic duties. It might even be possible for a Christian to use secular authority to mitigate violence and injustice rather than passively allowing it (Müller 1922, p. 244).

Although this was a clear change from the original separatism of Chelčický and Gregory, the Unity's political doctrine was still quite different from Augustine's theology of the "two cities" that had guided the church for centuries (Augustine of Hippo 1958). In fact, Christians should participate in civic life, within the bounds of Christian morality, as part of their Christian devotion. In the 16th century, Luther reaffirmed Augustine's theory with his own "two-kingdom" theory. Good Christians should be willing even to serve as executioners (Bainton 1978, pp. 184-90; Ozment 1992, pp. 118-48; Luther 1962, pp. 75-128). Here, as in other matters, the Brethren's perspective differed markedly from Luther's: they continued to use the dictates of the Sermon on the Mount to mitigate the state's propensity to violence and cruelty. The same ethic of love must be applied to civic life as well as personal life. Not all were happy with the Brandýs decision, especially a soap maker named Amos, and soon after, the Unity split into a Major Party that embraced the more relaxed rules and a Minor Party that insisted that the commandments of the Sermon on the Mount are absolute and binding on all Christians in all circumstances (Peschke 1981, pp. 123-24). Gradually, Chelčický faded in the memory of the Unity, and even Gregory was acknowledged as little more than an early organizer with extreme views. Remnants of the Old Brethren could be found as late as the middle of the 16th century, but it appears that most of the Old Brethren united with the Hutterites and other Anabaptist groups after 1528 (Zeman 1969).

In addition to the controversy over the Brethren's relationship to secular authority discussed at the Brandýs Synod, there were also robust discussions about the relationship of faith and works. There was a general consensus among the Brethren that signs 
of religiosity, such as pilgrimages, did not lead to salvation. True assurance of salvation comes from, as historian Rudolf Řićan put it: "deeds flowing from the depths of a believing and repentant heart, suffering for Christ, and the life of self-denial" which were "evidence of genuine faith for which they expected as their reward salvation and eternal joy." (Ǩíčan 1992, p. 56). Though all agreed that faith must be completed in love in order for one to have genuine hope of heaven, some of the more theologically literate Brethren cautioned against the belief that good works alone (especially mortification of the flesh) can lead to salvation. "Is a life of great renunciation required, which calls for constant fear of enjoying the world too much, to the extent that even to drink one's fill of water with enjoyment is considered a sin and troubling to one's conscience, yet without having peace?" (Říčan 1992, p. 58).

The Brethren's priests and teachers searched the New Testament for guidance on the proper role of asceticism. In addition to the passages calling for denial of the body and renunciation of the world that Gregory had cited, the Gospels also show that Jesus attended feasts and even made wine (John 2). Some of the Brethren pointed to the Apostle Paul's warning to the Galatians against those who replaced grace with the law and his statements that people cannot be made righteous through the law, but only through faith. How could this be reconciled with the strict rules of the Unity? ${ }^{11}$ Luke of Prague reported as early as the 1470s that "many read in the scripture that Christ's yoke is easy and light, but it was actually hard and difficult" to live according to the Unity's rules. ${ }^{12}$ Could it be that the Unity was making the way of Christ too hard and creating unnecessary difficulties for people?

Younger, better-educated priests formed a "grace party" that argued for relaxation of asceticism and a recognition of the goodness of creation. Luke of Prague (d. 1528), who had been educated at the University of Prague, gradually emerged as the intellectual leader of the grace party and was eventually elected to the Inner Council. Whereas the Minor Party (also called the Old Brethren) argued that the Sermon on the Mount must be taken literally, "Luke distinguished between the law of grace and the written word of the Bible." (Peschke 1981, p. 142). The law of grace is spoken by God directly to the believer's heart, and its content is faith, love, and hope. Luke reminded the Brethren that the gospel existed before the New Testament was written. In fact, the reason the New Testament had to be written was because early Christians began wrangling over doctrinal matters rather than holding fast to the simple truth of salvation (Peschke 1981, pp. 142-44). Luke went so far as to publish a defense of taking oaths, based on Scripture, which argued for the goodness of oath-taking in certain circumstances.

Rather than the legalism of Gregory, Luke proposed a more nuanced process of ethical discernment within the community of faith. The ideal that they held up for the community was still characterized by the rejection of worldly values of domination, control, violence, power, and invulnerability. The blessings associated with salvation and the gifts of the sanctifying Spirit remained those of the Beatitudes: poverty of spirit, gentleness, mourning, hungering for righteousness, mercy, purity of heart, peacefulness, and redemptive suffering (Atwood 2007, pp. 91-118). In addition to the foundational biblical commandments given in the Catechism, the Inner Council issued instructions on proper secular employments and social behavior that were an integral part of the theology and practice of the Unity throughout the 16th century. For instance, nobles and scholars who were "ready to comport themselves on an equal footing with the poor and unlettered, undergoing shame and danger with us" were welcome in the Unity (Brock 1957, p. 221). After 1500, the Unity allowed members to engage in commerce if they could trade honestly, without greed or conspicuous consumption (Brock 1957, p. 151). In all businesses, the Unity reminded its members that business ethics was part of their Christian duty. The customer is "a neighbor, to whom was due love and readiness for service. Only a just profit was allowed. In all, the tradesman had to love righteousness." (Říčan 1992, p. 81).

The key to interpreting the Brethren's ability to adapt its doctrine to changing historical circumstances is that they distinguished between things that are essential to salvation, those 
that are ministrative to salvation, and things that are incidental matters. At least since Augustine, theologians had distinguished between essential matters and "adiaphora" or incidental matters, but the Unity added the middle term of ministerial or ministrative things. As the historian Amedeo Molnár put it: "Ministrative things for them were those which the Holy Spirit uses as a tool for imparting the essential things. Because of their character as tools and objects of service, it is not permissible to call them incidental things." 13 This distinction appeared in the early confessions of the Unity, but it was refined as a theological concept by Luke of Prague during the struggle over faith, works, and asceticism (Štrupl 1964, p. 281).

For the Brethren in the 16th century, there are six essential things. Three are works of God (creating, redeeming, and sanctification) and three-fold human response of faith, love, and hope. True faith was expressed in obedience to the Law of Christ, especially the commandment to love one's neighbors and one's enemies; therefore, ethics remained a central part of the Unity's doctrine (Štrupl 1964, p. 281). Hope is the consequence of belief, obedience, and genuine love for God and one's neighbor. It was hope for heaven and the vindication of the righteous rather than hope for better times in this life. True hope brings blessedness even in the midst of a difficult and threatening world because it is rooted in the trust that God will do what God promised (Müller 1922, p. 218). In short, the Unity rejected outward signs of religiosity in favor of inner disposition and ethical behavior: "deeds flowing from the depths of a believing and repentant heart, suffering for Christ, and the life of self-denial were seen as evidence of genuine faith for which they expected as their reward salvation and eternal joy." (Říčan 1992, p. 56).

The ministerial things mediate the work of God in salvation, but they do not save in themselves. The Unity recognized that humans can and do misuse the ministerial things and make them unholy by using them to oppress rather than to save. This is why they rejected "evil priests" in the Catholic and Utraquist churches (Müller 1922, p. 200). They knew from experience that inquisitors and executioners quoted Scripture and that priests absolved those who engaged in bloodshed, rape, and pillage. The Bible was foremost among the ministerial things. It was understood less as a book of profound theological insight or eschatological mystery than as a guide to faithful living in the here and now. The Brethren believed that the New Testament had greater force and was to be preferred in matters of faith and practice because, unlike the Old Testament, it "neither condemns to death ... nor coerces anyone to fulfill its commandments, but rather with loving patience calls for repentance, leaving the impenitent to the last judgement." (Brock 1957, p. 86) From the Old Testament, the Brethren particularly valued the Psalms, Ecclesiastes, and Proverbs. They also valued the Wisdom of Solomon from the Apocrypha (Říčan 1992, p. 54; Müller 1922, p. 198). For the Brethren, though, the Word of God was not simply the Bible. Many Brethren, including Comenius, believed in the possibility that God continues to speak through prophets who could foretell the future. Daniel Larangé argues that preaching functioned as a fundamental activity of religious life and practice within the Unity tradition. He suggests that between Hus and Comenius, preaching reflected the heart of the liturgy in the sense that it accommodated the proclamation of the gospel that worked to create a spiritual community. The Unity of the Brethren situated the Word of God at the center of religious practice and worship. According to Larangé, Comenius believed that preaching provided an intersection between dialectics and rhetoric, for the purpose of perfecting communication between God and humanity (Larangé 2008, pp. 389-462).

True to the teaching of Hus and Wyclif, the Unity taught that the "essential church" is the invisible body of the elect throughout time and space (Müller 1922, p. 198). This "catholic" church did not have an organization, priests, or sacraments because Christ himself is high priest, but there was a "ministerial" or visible church that strives to be a model of the true church in which the elect learn to live in the eschatological community (Štrupl 1964, p. 285). The ministerial church was a gathering in time and space of humans who believe in the Lord Jesus Christ. It was a church of servants who use the ministerial things (priesthood, sacraments, worship) to lead people to the knowledge of the true God and Jesus Christ whom he sent (Müller 1922, p. 199). Unlike other ecclesiastical 
bodies during the Reformation era, the Unity of the Brethren openly acknowledged that the true church could be manifested in different types of brotherhoods. Furthermore, the Brethren taught that there is salvation outside of the visible church; however, there was no salvation outside of the "invisible church" because by definition it is the invisible body of those saved.

The next most important ministerial things were the seven sacraments. The Unity was deeply concerned about sacramental theology and practice, and they drew heavily on the theology of the Church of Tábor, especially in their understanding of the Eucharist and confirmation. From the beginning, the Brethren agreed that it was wrong to elevate the host or to bow to it, which they equated with idolatry. Connected to this was their rejection of the idea of transubstantiation and ceremonialism in the mass. They used normal bread and wine served in everyday vessels for Holy Communion. They also asserted that the bread and wine are the body and blood of Christ only during the reception of communion; therefore, the host should not be reserved in a pyx after the ceremony (Ř́čan 1992, pp. 30-31). Along with the simplification of the Lord's Supper, the Brethren abolished the use of "sacramentals," such as holy oil, holy water, and the blessing of objects (Müller 1922, p. 77).

Under Luke, the Unity was more open to the broad Christian tradition, especially in hymnody. The Brethren's hymnals of 1501, 1505, and 1519 included hymns from the Utraquist and Táborite churches as well as new compositions by Luke himself. Luke also translated several Latin hymns and chants from the old Latin missal. ${ }^{14}$ One of Luke's great achievements was the writing of a catechism, Dětinské Otázky (Children's Questions), which was also known as Catechism for the Young in Faith. Luke's catechism was based on Táborite catechisms, Hus' Exposition of the Faith, and the teachings of Gregory. The catechism identified the summary of the Law of Christ as love of God (Deut. 6: 4-5) and love of neighbor (Lev. 19: 18). The gospels recorded this as Jesus' own interpretation of the Torah (Mark 12: 28-34), which "is more important than all burnt offerings and sacrifices."15

It would be hard to overemphasize the fact that ethics was central rather than peripheral to the theology of the Unity because faith must be completed in love. Personal morality and social ethics were viewed as aspects of love of God that are essential elements of human happiness and salvation. One of the major tasks of the community of faith, therefore, is to teach Christian ethics by word, example, and mutual discipline. The Brethren interpreted the statement that "God is love" (I John 4: 16) to mean that the essence of God is to produce goodness through creation, redemption, and blessing. The faithful experience eternal life in this life and the next through faith. ${ }^{16}$ Children at confirmation and new members at baptism were questioned about sinful desires or "deadly appetites," the twin forces of self-aggrandizement and self-destruction. The Unity drew upon Catholic tradition in identifying the deceptive desires as "seven mortal sins:" Pride, Greed, Unchastity, Envy, Gluttony, Anger, and Sloth. Luke interpreted these vices in terms of the rejection of a corrupt society. Mortal sins were the source of violence, abuse, and injustice in the world. In contrast, the true community of the faithful is characterized by "humility and obedience, submission to the ordinances, with singleness of mind in the acceptance of teaching, admonition, warning, punishment, and diligent keeping of the commandments of God, and [following] the good morals of the servants of the truth [I Cor. 15: 33]."17

The Unity did not abandon its foundational idea of complete separation of secular and spiritual authority when it gave permission for members of the Unity to participate cautiously in civic affairs. Humans only have a secondary power that has been granted by God, but must not be confused with God. Secular power promotes justice and well-being in the human community, but it should not be allowed to interfere in matters of conscience or the affairs of the church (Řičan 1992, p. 70). By declaring the secular power subordinate to the authority of God rather than representative of God's authority, the Unity preserved a principle of conscientious rebellion and non-cooperation with demands of the state when those demands were contrary to the teaching of the gospel. In other words, after the schism, the Unity still retained its character as a "free church" operating under its own understanding of the will of God. For Luke, the word "antichrist" meant any force in 
the world that opposes the goodness of Christ and human salvation. He used the term frequently for the Roman Church, but it could be anything that encourages sin rather than salvation. The true church of Christ speaks the truth, the other lies. "Christ gathers, but the antichrist scatters. The one gives life, the other kills. The one is humble, the other raises itself above all that God has named.... The one is a servant even unto death, the other is the master for whom others must die." (Peschke 1981, p. 155).

The "one, holy, catholic, and apostolic church," according to Luke, is the "assembly of those elected by God, which shall reign eternally in heaven with Christ in the choir of angels, whose names and number are known only by the one who has made them, redeemed, and made them blessed." They are not defined by a particular time or place, or type of church or law, but are called out of "all peoples and tongues from the beginning until the end." 18 All who have a "new birth of spiritual life, renewal of the spirit and conscience, improvement of understanding, thoughts, and will in divine righteousness from faith in Jesus Christ and in practical evidence of faith in their works" are part of the true church (Müller 1922, p. 460).

Much of the theological writings of the Brethren concerned the sacraments because they were forced repeatedly to defend themselves from the charge that they were Pikards who denied the Real Presence of Christ in the Eucharist. Even though Luke was critical of Catholic definitions of the sacraments, he defended the traditional seven sacraments as visible means to confer spiritual blessings according to apostolic tradition (Müller 1922, p. 466). The sacraments were given to the church by Christ and the apostles as "sign and witness" of the faith, but they were holy only in so far as they pointed believers to God, who is holy. The sacraments have no power as signs and witnesses without the preaching of the gospel (Müller 1922, p. 464).

In his 1511 work Apologia Sacre Scripture, Luke clarified the Brethren's teaching on the Eucharist, which rested on the words of Scripture "this is my body; this is my blood" without the need for philosophical explanations (Burnett 2018, pp. 210-11). Christ has four distinct modes of existence according to Luke (Müller 1887, p. 105; Peschke 1981, pp. 161-65). "First of all, he is substantially, naturally, physically, and locally (dimensionaliter) present only in heaven. He will be present in this way on earth only at the Last Judgment. Secondly, he is currently present powerfully or regally on earth since he reigns as king (Matt. 28: 18). His third mode of being is spiritually in the church, in the hearts of the faithful, and through his gifts of grace (Matt. 18: 20). The fourth mode is his sacramental presence, which is unique to the sacrament as "a sensual sign of a spiritual truth." (Peschke 1981, pp. 166-68). Christ is not physically present in the sacrament, but the consecrated bread and wine communicate Christ "spiritually, actually, and truthfully" to the one who eats in faith (Müller 1922, p. 487). Christ's flesh is not present, but his spirit is present (I Cor. 11: 27), and in this way, the sacrament itself provides an "essential truth" to believers through the act of eating and drinking (Müller 1922, p. 488). True to the teaching of the Unity, Luke rejected the practice of showing obeisance to the consecrated host, which he saw as a form of idolatry that must not be tolerated.

Luke devoted a great deal of attention to the sacrament of ordination and the proper role of priests in the church. He provided a new liturgy for ordination in 1501 that served as a commentary on the meaning of priesthood. Householders were to be priests in the home, and ordained priests were to be the fathers in the church. In 1518, the Inner Council approved Luke's Instructions for the Priestly Office in the Unity of the Brethren (Zprávy knězké), which was printed in 1527 . This appears to have been the first work of pastoral theology ever published by a non-Catholic church in the West. Thus, it is a very important work in the history of Western Christianity. In it, Luke set forth qualifications for priesthood that included internal calling and faith along with proper education and intense preparation for the work of the priesthood (Říčan 1992, pp. 103-5). Christ's priesthood, according to Luke, is eternal while the ministry of human priests is only for a time. They are only truly priests when their ministry mediates the grace of Christ (Müller 1922, p. 500). Priests were expected to preach, teach, and care for souls. This included counseling the fallen, hearing 
confessions of the penitent, showing the impenitent the way to penitence, and disciplining those who refuse to repent. In addition, they were to visit the sick in order to comfort them, pray with them, and strengthen their hope in the face of death. Priests helped parents choose godparents for their children at baptism and guided the children's instruction in the faith as they grew (Müller 1922, p. 284).

\section{Part 2-The Brethren and the Reformation}

\subsection{Erasmus and the Brethren}

Under Luke of Prague, the Unity of the Brethren was organized as an independent church with its own priesthood, doctrine, and liturgy. It had resolved its crisis over faith and works, and it had become more open to the outside world. Surprisingly, though, around this time the Brethren came to the attention of the Dutch humanist Desiderius Erasmus (1466-1536). A Czech humanist named Jan Šlechta wrote a long letter to Erasmus describing the three Czech churches: Catholic, Utraquist, and Pikarts (the Unity). He depicted the Brethren as ignorant heretics, but to everyone's surprise Erasmus replied to the letter with a public defense of the Unity (Müller 1922, pp. 392-94). Erasmus often described his own theology as "the Philosophy of Christ" based on the example of Christ and his teachings, especially the Sermon on the Mount, which was "more real and precious than any material relics of him that could be found." (Phillips 1949, p. 81). He expressed approval for the Unity's conscientious efforts to remove unworthy priests from office and how they imposed stricter discipline in the church. He held the Brethren up as a model that the Catholic Church should emulate rather than fear. Erasmus also drew on his knowledge of early Christianity to defend the fact that the Brethren chose their own priests, noting that this had been the practice of the early church. Erasmus even affirmed the Brethren's practice of calling each other "brother" and "sister," but only so long as their actions matched their language (Müller 1922, p. 394). The one area of the Brethren's doctrine that Erasmus did not endorse was their teaching on the Eucharist because it seemed impious to him not to kneel after the consecration of the host. However, he was supportive of their simplified liturgical calendar and worship (Müller 1922, p. 394).

The Brethren were so encouraged by this defense from one of the most respected scholars of the age that they sent a delegation to present Luke of Prague's Apology of Sacred Scripture to Erasmus in the hope he would have it published with his endorsement. Though Erasmus expressed his general support for their simple approach to the Christian life, he returned the Apology, prudently noting that it would be extremely dangerous for him to publish it since he was already under suspicion for heresy. Moreover, he informed the Brethren that his endorsement would actually do little to help the Unity in their cause (Müller 1922, p. 395). Erasmus was aware of the limits of his influence in the halls of power.

It is, however, illuminating that the Unity recognized a kindred spirit in Erasmus who seems so different from them on the surface (Molnár 1987, pp. 185-97). Though Erasmus lived in a sophisticated world far removed from that of the village life of the Brethren, Erasmus also used the Bible as a guide for practical Christianity in a complicated world. He believed in the God-given rationality of ordinary people who could, with the grace of Christ, make moral choices. Education had the potential to help people make better use of their intelligence and will in daily living. Like Erasmus, the Brethren did not adopt the pessimistic understanding of the human will that one sees in Luther and Calvin. They certainly understood from their own experience that sin is pervasive and deceptive, but their writings did not dwell on human weakness and depravity. The humanists and Brethren also shared a mutual interest in pedagogy. The priests of the Unity were teachers as well as pastors. Unlike Erasmus, though, the Brethren were educating the children of farmers, craftsmen, and other common people rather than aristocrats.

\subsection{Luther and the Brethren}

It is time to return to where we started: Luther and the Brethren. Soon after the Disputation at Leipzig, Luther became acquainted with the writings of the Unity of the 
Brethren, particularly Luke's Defense of Sacred Scripture, which he read in 1519 . He decided that the Brethren were faithful to Scripture and the doctrine of the early church; it was the papacy that was heretical. In 1520, he publicly endorsed the practice of communion in both kinds, using the arguments of the Utraquists and pointing to their example for support (Peschke 1981, pp. 185-89). Soon, reformist propaganda was widely distributed that depicted Luther and Hus together serving the chalice to the laity and preaching from the Bible (Scribner 1994, pp. 220-27). In 1520, Luther wrote to George Spalatin, "Without being aware of it, I have until now taught and held the whole doctrine of Jan Hus. In short, we are all Hussites without knowing it. Even Paul and Augustine are really Hussites."19 Luther, who had once been too frightened to say the words of consecration at the Eucharist, had aligned himself with the most feared heretics in history.

When news of Luther's surprising declaration of affinity with Hus reached Prague, the Utraquists welcomed him as an ally in their long struggle. They sent a delegation to Wittenberg to present Luther with a copy of Hus' De ecclesia. He declared that once he read Hus for himself: "the joy of my heart began, and, looking around at all those whom the pope had condemned and damned as heretics, I praised them as saints and martyrs, especially those whose pious writings or confessions I could find." (Pelikan and Hotchkiss 2003, p. 800). Relations were established between Prague and Wittenberg, and some of Luther's works were translated into Czech. Some of the Utraquist priests and nobles were attracted to the German reformer's ideas and formed a "Luther party" that sought to bring the Utraquist Church into closer conformity to the Lutheran church (Müller 1922, pp. 396-97). Called Neo-Utraquists by later historians, the Luther party probably had less impact on the Bohemian national church than was once believed. The majority of Utraquists rejected Luther's teaching, especially "his sola fideism, his principle of sola scriptura, and his rejection of sacramental priesthood in historic apostolic succession, including the papacy." ${ }^{20}$ Luther, in turn, was very critical of the Utraquists' commitment to apostolic succession, the veneration of saints, prayers for the dead, and other Catholic elements of their faith and practice. Several Bohemian nobles, however, openly identified themselves as Lutheran and agitated for the right to introduce Lutheranism on their estates. In 1575, Lutheran nobles and the Brethren signed a joint confession of faith called the Bohemian Confession, which was later eventually endorsed by the Utraquists as well (Molnár 1973, pp. 241-47; David 1999, pp. 294-336; David 2003, pp. 168-97).

There was more common ground between Luther and the Brethren than between Lutheran and the Utraquists. The Brethren Jan Roh (or Horn) (c.1485-1546) and Michael Weisse were studying for the priesthood in the Unity when they read Luther's early works. In May 1522, they and some companions traveled to Wittenberg to study with Luther and Melanchthon. The two reformers quizzed them repeatedly on the question of whether the Brethren really were Pikards as their enemies claimed. Following this interview, Luther publicly defended the Unity of the Brethren as a Christian church separate from Rome even though he was critical of their understanding of the Eucharist (Müller 1922, pp. 400-6). Roh and Weisse helped establish friendly relationships between the Inner Council and Luther, but the aged Luke of Prague replied to Luther's criticisms of the Brethren's doctrine. "The Brethren follow a better way, in that they actually follow thoroughly the simplicity of faith in the holy Gospel and the model of the first church; above all, they free themselves from all that runs contrary to it and give warning of such things, and they actually follow the truth of faith without anger." Luke told Luther that the church should focus on faith, love, and hope rather than demanding more precision on the presence of Christ in the Eucharist than what is stated in the Bible. Jesus simply said, "This is my body. This is my blood." Jesus did not say of the bread and wine: "this is Christ, the true God and true Man, the Redeemer and Savior." (Müller 1922, p. 407). In 1523, Luther published a tract titled On the Adoration of the Sacrament (Von anbeten des Sakraments) in direct response to Luke's treatment of the sacraments (Luther 1962, pp. 269-305). Luther was critical of the Brethren's refusal to kneel before the consecrated host because their practice indicated that they were indeed Pikards despite their claims to the contrary. 
Luther, however, showed deference to Luke and the Brethren that he did not show to other evangelicals with whom he disagreed. In 1522, he published Luke's Children's Questions in German and personally composed a preface. This meant that the Unity had the honor of publishing the first Protestant catechism. Despite its evident weaknesses in style, Luke's Children's Questions served as a valuable model for other Protestant catechisms, including Luther's own catechisms (Müller 1922, p. 409). However, Luther openly questioned the Brethren's teaching that infant baptism needed to be completed in confirmation. Luther maintained a belief that original sin is washed away in baptism; it is a complete sacrament in itself. He wrote, "Therefore it is our judgment that through the faith and prayer of the church young children are cleansed of unbelief and of the devil and are endowed with faith, and thus are baptized." (Luther 1962, p. 300). Luke, in contrast, argued that baptism is an act of the church that anticipates the future profession of faith of the child. Baptism does not make a person Christian; repentance and profession of faith do that. Luke also emphasized that unbaptized infants are not subject to punishment but are saved by God's grace (Müller 1922, pp. 468-80). Historian Elsie McKee claimed that the Brethren's belief that baptism was not necessary for salvation, which was written into their hymnal, was particularly appealing to women during the German Reformation because it meant that unbaptized infants who died went to heaven (McKee 1994, p. 56).

Formal relationships between Luke of Prague and Luther ended around 1525. It may have simply been the case that Luke was too old to continue the debate and discussion, but historian Rudolf Říčan speculated that Luther's support of the princes during the Peasants' War was decisive for Luke. "We cannot help but suspect that Lukas as leader of the Unity, constantly standing vigilant against the use of secular power for the oppression of subjects and the cruel exercise of feudal rights, had even more reason for not continuing relations with Wittenberg." (Říčan 1992, p. 116).

After the death of Luke in 1528, the Unity elected a new Inner Council, which included a new Senior, Jan Roh, who viewed the German Reformation as a fulfillment of the promise of Hus's reforming work. The fact that Roh received the most votes for Inner Council indicates that his views had strong support among the clergy. Even so, many of the older Brethren expressed fears that closer ties to Wittenberg and Luther's doctrine of justification by faith alone would undermine the discipline of the Unity. They also feared the corrosive effect that higher education and involvement with the wider world might have on a church that had always valued simplicity, manual labor, and strict morality. Despite such cautions, the new Unity leadership made significant changes in doctrine and practice in response to Luther's reforms. $^{21}$

Roh established his residence and a school in a former Franciscan cloister named Karmel in Mladá Boleslav. The Unity maintained a printing press there, and the Inner Council began to give greater attention to formal education, especially higher education for the clergy. Roh was instrumental in the decision of the synod of 1531 to "set aside" the writings of Luke, which were considered dry, scholastic, and hard to understand. Under Roh, the Brethren's priests were encouraged to use contemporary theological resources, such as Melanchthon's Loci communes, in their teaching and preaching rather than repeating what was said in the past. Luke's Children's Questions was revised in a livelier and simpler form and republished as the Catechism (Müller 1922, pp. 4-6).

In 1531, Michael Weisse published his German translation of the Brethren's hymnal. This Gesangbuch introduced German-speaking Protestants to the theology of the Brethren and was reprinted four times in Ulm from 1538-1540 (McKee 1994, p. 7). The hymnal included hymns focused on the life of Christ (incarnation, birth, circumcision, epiphany, ministry and sufferings, resurrection and ascension), which corresponded to the major holy days of the medieval church. There were also hymns for use throughout the day, which recalled the monastic daily office. There was a specific collection of hymns for children, reflecting the Brethren's interest in education and family life, and hymns for those who have fallen away from the faith. In addition to hymns for funerals and the final judgment, Weisse included hymns designed to teach people the proper way to honor the 
saints, especially the Virgin Mary (McKee 1994, p. 18). It is evident that Weisse's hymnal conformed closely to the major themes of the Brethren's catechism.

The Brethren's synod of 1531 decided to simplify the liturgical calendar, removing many saints' days, and standardizing the order of worship for congregations. The new instructions for worship were announced in 1534. Changes in communion practice, such as the required use of unleavened wafers, altar cloths, candles, and nicer chalices, demonstrate the influence of the Lutherans on the Unity. The Inner Council encouraged these changes so that the Unity would "not be unnecessarily separated from other people." (Müller 1922, pp. 12-13). One of the most significant changes made by the Inner Council concerned baptism. They published a denunciation of the practice of rebaptism, perhaps as a way to distance themselves from the Anabaptists. Parents and sponsors were instructed to lay their hands on the baby at the time of blessing to emphasize that baptism was an act of the church, not the priest alone. Baptism was to be done with clean water poured three times with the words "in the name of the Father, and the Son, and the Holy Spirit, as the Lord Christ has commanded." (Müller 1922, p. 13).

One of the most remarkable signs of the close ties between Luther and the Unity was that Luther published in German translation two versions of the Unity's confession of faith (1532 and 1535). Luther provided a preface that spoke in favor of the Brethren, who were "no longer as hateful to me as they had been while I was a papist. I finally found among them a unique and great miracle, almost unheard of in the pope's church, namely, that, leaving aside human doctrines, they meditated in the law of the Lord day and night and were experienced and equipped in the Scriptures." (Pelikan and Hotchkiss 2003, p. 800). He noted that it was surprising how sophisticated their theology was since they were hindered by poverty and lack of education.

In 1532, Jan Augusta (1500-1572) was made a member of the Inner Council and consecrated a bishop. He proved to be one of the most energetic, effective, and controversial leaders of the Unity. Roh and Augusta recognized that Luther's unexpected success in Germany meant that the Unity was no longer a pariah in Christianity. For decades, their core teachings had been condemned as heretical and dangerous by theologians and monarchs alike, but now some elements of their doctrine were being taught and preached in universities and parishes from Saxony to England. It was no wonder that for a brief, shining moment some of the Brethren believed that it was possible that Western Christianity could unite under an evangelical banner with the Unity accorded special honor as the pioneer of a renewed and apostolic church. Though he died before it was written, the Bohemian Confession of 1575 reflected Augusta's efforts at Protestant union in Bohemia.

One of the new Lutheran aspects in Augusta's preaching and writing was the importance of joy in believing (Řičan 1992, p. 128). In 1532, the Inner Council also moderated the Brethren's traditional instructions for right living, called the Decrees or Dekrety, to promote more openness to secular society (Müller 1922, pp. 16-21). Marriage was no longer merely tolerated as a means of reproduction and a way to avoid fornication; it was described as a blessed union of two souls who delight in one another and in the Lord (Řičan 1992, p. 128). Likewise, parents were told that they should view children as precious gifts of God and take delight in them. They should gradually and patiently teach children the Ten Commandments, the Lord's Prayer, the hymns of the Brethren, and explain the meaning of the worship services. Mothers and fathers alike were instructed to repeat the story of Jesus frequently and remind their children of the grace and love of God (Müller 1922, p. 22).

Augusta published A Conversation Between a Scholar, who Loves the Honor and Pleasure of the World More than God, and an Uneducated Man who is Merely a Farmer but who Knows God and Salvation to show that simple faith is wiser than the subtleties of the learned and powerful (Müller 1922, pp. 78-81). Augusta's farmer uses scriptural quotations to convince a scholar that the Bible offers believers assurance of salvation for those who have faith. Catholic doctrine, the farmer asserts, was intended to keep people in anxiety about their eternal destiny so that they could be more easily led and be more willing to spend their money for masses, indulgences, and other ways of "buying" salvation (Müller 1922, p. 80). 
Much has been made of the Brethren's adoption of Lutheran teaching under the leadership of Augusta, but it is easy to overstate this (Štrupl 1964, p. 280). The turn toward Lutheranism in the Unity was genuine but not complete. Those who joined the Unity after 1532 continued to make a public break with the established church and "promised to follow Christ under the cross in obedience to the priests as to servants of Christ in the bond of peace and love; and committed themselves to an honest life and to keeping the rules of order." (Ř́čan 1992, p. 153). In 1538, the Inner Council informed the Brethren that several things were forbidden "under pain of expulsion," including suing a brother or sister in secular court, contracting a marriage without the permission of one's parents, shameless speech, slanders, visiting taverns, gaming, dancing, and luxurious clothing. Members were forbidden to loan money for interest because that was one way that the poor were oppressed by the rich. Interestingly, elderly persons, especially widows, were allowed to loan money for interest to the wealthy. Tavern owners were instructed not to serve alcohol to drunk or unruly people. Oaths were permitted only "if done in the name of the Lord, within given limits, and with complete sincerity in the interest of love and righteousness." ( Ǩičan 1992, pp. 161-62). Such a list of forbidden behaviors went far beyond the discipline of the Lutherans, and Luther himself frequently criticized the Brethren for potentially undermining the gospel with works of righteousness.

The most visible impact of Lutheran teaching on the Brethren was in sacramental theology and practice. The Brethren adopted Luther's teaching that the only true sacraments are baptism and the Eucharist, but this had less impact on actual church life than one might expect since the other five sacraments were retained as "rites" with little or no change in either their practice or doctrine regarding them. The Brethren consistently rejected Luther's idea that Christ's physical body and blood are present along with the bread and wine after consecration (consubstantiation rather than transubstantiation). Likewise, the Lutheran doctrine of the ubiquity of Christ whereby Christ is physically present on every altar each Sunday made no sense to the Brethren (Hägglund 1968, pp. 239-44; Pelikan 1983, pp. 190-203). Christ was sacramentally present in the Eucharist, not physically present. So, while it is correct to say that the Unity's revised communion liturgy demonstrated the influence of Luther, this should not be taken as evidence that the Unity adopted Lutheran sacramental theology (Müller 1922, p. 25).

Likewise, the Brethren did not adopt Luther's dichotomy of Law and Gospel. They maintained their traditional teaching that those who are saved by faith need to fulfill Christ's commandments; faith must be completed in love. In general, the Brethren viewed Lutheran doctrine as incomplete. This was so

because they were preaching righteousness gained from faith without any works of faith; because they were not doing justice to the full meaning of the Lord's Supper, because in the Apostles' Creed they were giving prominence to faith in Christ while passing over the other articles, because they did not base their teaching on the whole of Scripture, and particularly because ... they taught as if salvation was obtainable through faith alone without the agency of the church and its servants. (Říčan 1992, pp. 119-20)

In general, the Unity remained closer in spirit to Philip Melanchthon than Luther, and the Inner Council maintained a good relationship with Lutherans as long as Melanchthon's voice was prominent.

Because of a renewed persecution in the 1540s, many Brethren fled to Prussia and Poland where they established permanent congregations. A list of a group of immigrants to Prussia gives an interesting picture of the Unity in the 16th century: five millers, one baker, three cobblers, two clothiers, two coopers, at least one cutler, locksmith, joiner, rope maker, tailor, vintner, two clerks, and a schoolmaster. The Brethren found they had more freedom in Poland than in Prussia where the elders were required to submit to the rulings of the Lutheran authorities and adopt Lutheran liturgy and vestments (Říčan 1992, p. 187). It seemed to some of the Brethren that these Lutheran restrictions were as bad as the conditions they had left in Bohemia. The Brethren's position in Prussia worsened 
during the Osiander controversy in the Lutheran church. Andreas Osiander taught that Christ makes one righteous rather than merely declaring that one is justified. "By his divine nature he resided in a person and thus made that person righteous." (Pelikan 1983, pp. 150-52). This view was declared heretical by the strict Lutherans, led by Matthias Flacius. When the Lutheran authorities in Prussia in 1574 required that all Protestants affirm the teaching that people are declared righteous rather than made righteous by Christ, most of the Brethren left. They argued that such "theological disputes were repugnant" and maintained their teaching that Christians do become righteous through the grace of Christ and the agency of the Holy Spirit (Říčan 1992, pp. 191-92). This dispute has some affinities to the doctrine of deification, a prominent concept in early Christianity (Fudge 2003, pp. 226-35).

The situation of the Unity was different in Poland. In 1555, representatives of the Brethren and Reformed in Lesser Poland met in Kozminek to discuss greater cooperation and even merger. The Reformed pastors agreed to accept the Brethren's Confession and order of worship, though the Reformed remained a separate church (Říčan 1992, p. 231). When the Polish reformer Jan Laski (1499-1560) returned from England, he affirmed the close ties of the Brethren and Reformed, and he promoted union with the Lutherans as well ( Ŕčan 1992, p. 233). Laski even wrote a history of the Brethren and an account of their church order in Latin. A portion of this was later published by John Amos Comenius

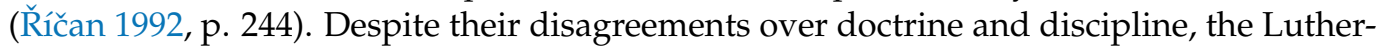
ans, Reformed, and Brethren in Poland recognized that they had much in common and could work together. After much conversation and negotiation, Protestant leaders signed the Sandomierz Agreement (Consensus Sandomiriensis) in 1570, uniting Protestants in the Polish-Lithuanian Empire. This was a great milestone in the history of ecumenism though it did not last long. The three Protestant churches issued a joint pronouncement (reces) that presented the basic doctrine of all three churches, leaving room for personal interpretation.

\subsection{The Brethren and the Reformed Tradition}

Ulrich Zwingli's works were also read in Bohemia in the 1520s. A few of the Brethren's priests, especially Jan Čížek and Michael Weisse, actively promoted Zwingli's writings within the Unity. They claimed that Zwingli's understanding of the Eucharist as a Zeichen (sign or signifier) meant the same thing as the Brethren's doctrine (Müller 1922, pp. 441-43). After years of trying to convince the Utraquists that the Brethren were not Pikards, Luke of Prague was not happy to find that some of his younger priests were using Zwingli's writings to argue that the Eucharist is a mere sign. Luke called a meeting of the Inner Council and wrote a harsh rejection of Zwingli and his teaching. Luke repeated the Brethren's traditional formula that Christ is present sacramentally, spiritually, powerfully, and truthfully in the bread and wine (Müller 1922, p. 444). The elders reaffirmed the view that "the sacrament was more than a symbol. Not only did it give honor to the grace of God, but at the same time it existed as grace and truth." (Říčan 1992, p. 118). When Čížek persisted in his Zwinglian teaching, he was expelled from the Unity. He grew more radical and in 1528 was burned at the stake as an Anabaptist by Catholic authorities. Weisse submitted to the elders, but he provoked further controversy by promoting Zwingli's idea that the "keys" given to the church simply meant the word of the gospel rather than the power to pronounce forgiveness after confession (Müller 1922, p. 444). Even after the Unity ceased referring to penance as a sacrament, they retained a traditional belief in the efficacy of confession and absolution by the church.

The 16th century reformer with whom the Brethren had the warmest relations was the humanist Martin Bucer of Strasbourg (see, Greschat 2004; Thompson 2005; Wright 1994; Selderhuis 1999). Though Bucer played a key role in the Reformation in Central Europe and England, as one biographer put it, "few figures of the Reformation era are so thoroughly forgotten." (Greschat 1990; Brady 1993, p. 129). This is unfortunate because Bucer did the most to promote unity between the German, Swiss, and English Reformations. In addition, "the city of Strasbourg was among the most important loci of liturgical development and 
renewal, for its leaders were especially interested in the doctrine of the church and the shaping of its practice." (McKee 1994, p. 3). It is not surprising that the Brethren, who had pioneered new forms of ecclesiology, worship, and church discipline, would come to the attention of the reformers in Strasbourg. Bucer knew the Unity by reputation and was interested in their church order before the Brethren had heard of him (Müller 1922, p. 116). It is interesting that Bucer promoted catechesis as a central aspect of the rite of confirmation in Protestantism, and it seems likely that his views were strongly influenced by the practice of the Brethren (McKee 1994, p. 14). There are clear parallels between Bucer's plans for the Reformed Church and the constitution of the Unity. Like Erasmus and the Brethren, Bucer's primary concern was that Christians learn how to live according to the teachings of Christ in their daily lives (Kittelson 1994, p. 94).

Direct contact was established between Bucer and the Brethren in 1540 after the Inner Council read Bucer's On the True Care of Souls and the Proper Service of the Shepherd, which they found similar to Luke of Prague's instructions to the priests. ${ }^{22}$ In response, they sent a letter to Bucer, delivered by Matthew Červenka and two companions, along with the Brethren's Confession of 1535. The delegation was warmly received in Strasbourg where they became acquainted with Bucer and his colleagues Wolfgang Capito and John Calvin (Müller 1922, p. 117). Calvin wrote to Augusta: "Therefore I will consider our congregations to be properly cultivated only if they are bound together by this union of order and discipline." (Říčan 1992, p. 151). Shortly after this, Calvin returned to Geneva where he instituted strict church discipline similar to that of the Brethren. When Bucer read the Brethren's account of their church life and discipline he declared: "You have a great gift of God, namely the bond of love, the unity of the Body of Christ, the church, an order and community of all your members. Where that is lacking the Lord Christ can neither be preached nor learned."(Müller 1922, p. 118). He singled out for praise their attention to the proper education of children, pre-marriage counselling, the work of the helpers and judges in the community, and wise exercise of discipline according to Matthew 18: 15-17.

Bucer was not the only reformer in Strasbourg to be impressed by the Brethren. Katherina Schütz Zell was one of the few women to write and publish material to support the Protestant Reformation and was an active participant in the theological debates of the 16th century (McKee 1998). As part of her effort to reform the religious life of the laity, Zell edited and published Michael Weisse's 1531 German version of the Brethren's hymnal. For the most part she left the texts of the hymns unchanged, but she did alter some of the musical settings (McKee 1994, p. 17). She added a preface that defended the practice of congregational singing and assured the laity that Weisse's hymnal provided hymns for the major festival days of the church that were being removed from the Reformed liturgical calendar (McKee 1994, p. 34). Zell specifically instructed that the Brethren's hymns would be good for singing in family devotions, while at work in the home, and to lull children to sleep. Zell may have been drawing on the Brethren's tradition of using women in pastoral roles (the Sister Judges), which included religious education of women in the home (McKee 1994, p. 40). What is most important for our purposes is that Zell and the other Strasbourg reformers recognized that the traditional theology of the Brethren, as communicated in their hymns, was useful for Protestant worship and teaching Protestant theology to the laity.

Amy Nelson Burnett has demonstrated that the Brethren's sacramental teachings were available to German and Swiss reformers in the 1520s and 1530s, especially Karlstadt, Oecolampadius, Bullinger, and Zwingli (Burnett 2011). Perhaps the figure most influenced by the Brethren was Martin Bucer whose ideas on the relationship of infant baptism and confirmation were close to those taught by the Brethren. Baptism, for Bucer, was more than just a sign; it was an entry into the koinonia or true community of the church that placed a mutual obligation on the one baptized and the church. He argued that when the apostles baptized people "they admitted them only into a school of piety and an apprenticeship in Christianity." 23 Like the Brethren, Bucer understood baptism as a "sacrament of education;" therefore, catechism and confirmation were necessary components of a Christian 
community (Wright 1994, pp. 147-48). Bucer's understanding of confirmation as "the public profession of faith and obedience, accompanied by congregational prayer and the imposition of hands" (Burnett 1994, p. 140) reflected the teaching of the Brethren. It is also probable that Bucer used Luke of Prague's idea of the "sacramental" presence of Christ in the Eucharist when attempting to mediate the dispute between Zwingli and Luther (Müller 1922, pp. 115-16). Bucer moved away from his earlier Zwinglian idea of the Eucharist as a mere mnemonic device to an understanding that the Eucharist is part of the self-giving of Christ to the believer (Hazlett 1994, pp. 72-82; Stephens 1970, pp. 238-59). For Bucer, as with the Brethren, through the power of the Holy Spirit, the believer receives the real, spiritual body and blood of Christ that unites each Christian in the invisible body of Christ.

Maligned by more dogmatic contemporaries, such as Heinrich Bullinger, as a "vacillator" and opportunist, Bucer shared the Unity's conviction that Christians should cooperate rather than oppose one another. ${ }^{24}$ It is illuminating that the Reformed theologians whom the Unity valued most highly (Melanchthon, Bucer, Capito) were the driving forces behind the Wittenberg Concord signed in 1536. The statement on the Eucharist echoes the language of the Unity: "with the bread and wine the body and blood of Christ are truly and substantially present" only during the act of communion (Pelikan and Hotchkiss 2003, p. 799). The Concord avoids the notion that Christ is physically present while affirming that he is truly spiritually present. In the words of Capito from 1530, "In this sacrament he gives of the true body and of the true blood truly to eat and drink for the nourishment of your souls and eternal life, that you may remain in him and he in you." (Kittelson 1975, p. 156).

The Brethren, in Molnár's estimation, correctly perceived "that the Calvinist teaching in great part set forth ... their own understanding of the gospel of Christ, the gracious demanding sovereign will of God, trust in the election of God, and a congregational community bound by discipline." 25 It is very intriguing that Bucer proposed the creation of voluntary, disciplined Christian communities (Christlichen Gemeinschaften) within a commonwealth after his encounters with the Brethren. ${ }^{26}$ Bucer's idea of little churches within the church would be revived by the Pietists in Germany in the 18th century.

There were two aspects of the Reformed Church that the Brethren did not embrace until late in the 16th century. One was the effort of Reformed ministers to have "godly" magistrates who would govern according to biblical law, including Old Testament laws, such as Calvin promoted in Geneva (Bozeman 1988). The Unity consistently, persistently, and intentionally rejected the idea that the secular authorities should use their coercive power to assist the church. The Brethren made no attempt to create a "holy commonwealth" like Geneva, the Palatinate, Scotland, or New England. They recognized that "the body of the elect" must by its nature be a minority community within any society (Ř́čan 1992, pp. 265-66). The Unity maintained a discipline that was at least as strict as that of Geneva, but the Brethren emphasized that discipline was always to be tempered by the law of love.

Calvin's famous "third use of the law" was appealing for the Brethren who had always been suspicious of Luther's strict division of Law and Gospel. Calvin believed that the biblical law is more than a means to restrain evildoers or to convince people of their need for grace. The law was also aspirational in that it shows the way believers could and should live (Calvin 1960, pp. 348-66; Pelikan 1983, pp. 212-17). However, the Brethren remained suspicious of the Calvinists' mingling of the law of the Old Testament and the Law of Christ in the New Covenant. For the most part, they retained their Christocentric hermeneutic. A sign of the growing connections with the Reformed came in 1581 when the Latin version of the Brethren's Confession was printed in Geneva in a collection of Reformed confessions of faith without the permission of the Inner Council. Future collections of Reformed confessions also included the Brethren's confession of faith, and increasingly the Brethren's congregations in Poland, Moravia, and Bohemia were listed along with Reformed churches (Říčan 1992, p. 269). The Unity also rejected the tendency of later Reformed scholars to engage in speculative theology. Molnár concluded that "the tangle and contention of theological disputes in the bosom of the western Reformation about the limits of orthodoxy, 
into which the Unity did not wish to be drawn, acted as a brake on the development of the individuality of the Brethren's approach to theology."27 The Brethren were especially suspicious of the doctrine of double predestination that asserted that God had predestined some souls to eternal damnation regardless of their works (Hägglund 1968, pp. 260-62). The Unity defined the church as the community of the elect without being overly concerned about who was not of the elect.

The greatest achievement of the Reformed humanists in the Unity was the production of the Brethren's Bible, which became known as the Kralice Bible in the 19th century. The Brethren's Bible became the Bible for all Czech Protestants, and in the 19th century, it was chosen by linguists as the standard for the Czech language. The first edition of the Bible appeared in several volumes over a period of many years. The translators worked from the Antwerp Polyglot, an edition of the Bible that included the Hebrew and Greek versions, which had been published by Catholic scholars in 1569-1572. The Brethren's Bible was printed on their press at Kralice. The Brethren's Bible included extensive interpretive notes taken primarily from the works of Reformed biblical scholars and theologians in Geneva, Heidelberg, and Herborn Academy in Nassau. ${ }^{28}$ Thus, the publication of the Bible in Czech moved the Brethren even closer to the international Reformed community of scholarship. In 1596, the Unity published a one-volume version of the Czech Bible without notes or commentary. This was adopted by Lutherans, Reformed, and Utraquists as the official Bible in Czech-speaking lands. The last printing of the whole Bible was completed in 1613 (Říčan 1992, pp. 271-72). During the Counter Reformation in Bohemia and Moravia, the Kralice printing press was destroyed and most copies of the Czech Bible were burned.

The trove of documents associated with the Brethren's priest Matouš Konečný (1569-1622) discovered in 2006 has the potential to expand our understanding of the Brethren's history in the years leading up to the 1618 defenestration of Prague and subsequent repression of Czech Protestantism in the early 17th century. This discovery in August 2006 consists of two chests of correspondence, numbering almost 200 letters, amid a total of about 600 documents that had been hidden in 1620 near Mladá Boleslav, forty miles northeast of Prague. The inventory consists of letters, financial registers, drafts, property records, prefaces and comments on a variety of literary and theological writings, a register of the publication and distribution of books printed by the Unity, among other documents belonging to Matouš Konečný (1569-1622), who was the bishop of the Unity and had previously studied in Wittenberg. One of the particularly valuable and useful documents is a worship schedule of a Unity of Brethren congregation near Mladá Boleslav covering a full decade from 1600 to 1610 . This repository makes possible new research avenues addressing the Unity of Brethren history, the nature and development of the church along with its nature and role in the religious history of Bohemia more generally. Many of the letters addressed to Bishop Matouš were written by Jan Lánecký (1554-1626), a Senior of the Unity based in Přerov in Moravia, and Matěj Cyrus (1566-1618), who represented the Unity of the Brethren at the Utraquist Consistory and who also occupied the pulpit in Hus' Bethlehem Chapel in Prague (http: / / matouskonecny.jbcr.cz, accessed on 5 March 2021).

\section{Conclusions}

Half a century before Luther posted his famous Ninety-five Theses, the Unity of the Brethren separated from the Catholic and Utraquist churches and established its own episcopacy, priesthood, liturgy, discipline, and doctrine. The study of the history of the Unity of the Brethren sheds light on the complexity and diversity of the Protestant Reformation. Contributions of the Brethren to Protestant history, doctrine, and practice have generally been overlooked by historians and theologians who tend to divide the reformation into the magisterial reformation (Lutheran, Reformed, Anglican) and the radical reformation (Anabaptists, Spiritualists). Its history reflects uniqueness as well as assimilation. There has been altogether too much emphasis on the latter and insufficient attention to the former. 
In many ways, the Brethren represent "a third way" between the magisterial and radical reformations. They rejected the concept of Christendom and advocated for voluntary gatherings of believers without rejecting other churches as heretical. They embraced many aspects of humanism while remaining critical of early capitalism. In some ways, the Brethren were closer in practice and spirit to Christian denominations in modern liberal democracies than any other Protestant churches during the Reformation. The history of the Unity of the Brethren suggests that Reformation preceded the sixteenth century and cannot be limited either to the Lutheran or Calvinist expressions of reformed religious doctrine and practice. The Czech inheritance of the later Middle Ages represents a discrete form of Christian Reformation and its contributions should neither be ignored nor minimized.

Funding: This research received no external funding.

Data Availability Statement: All data used in this article is available through research libraries and published sources.

Conflicts of Interest: The author declares no conflict of interest.

\section{Notes}

1 "Pickard" was a term of derision that was used by opponents of the Bohemian Brethren. The Pickards (also Pikard, Pikart) were a radical Hussite group that denied the real presence of Christ in community. They were largely exterminated by other Hussites during the Hussite Wars (1419-1437). The term was applied to the Bohemian Brethren in the Edict of St James (1508) in Bohemia, which allowed for persecution of anyone who denied the Real Presence or refused to kneel in the Eucharist. The history and ideas of this group have been elaborated in (Fudge 2016, pp. 183-202; Fudge 2014, pp. 1-30).

2 There have been a few studies on Luther's relationship to the Bohemian Reformation, most notably (Thomson 1953, pp. 160-81; Bittner 1954, pp. 107-29; Lohse 1965, pp. 108-22; Molnár 1983, pp. 627-39; Fudge 2002, pp. 31-48; Haberkern 2020, pp. 403-38).

3 For a summary of the early history of the Brethren, see (Halama 2020, pp. 371-402).

4 (Palmitessa 2014, pp. 1-42) provides a helpful survey both of Czech religious history and how this history has been interpreted and received. Few of the articles in the excellent online journal The Bohemian Reformation and Religious Practice (11 volumes so far) are about the Bohemian Brethren, http:/ / www.brrp.org (accessed on 15 February 2021).

5 (Horníčková and Šroněk 2016) provides helpful context for this history.

6 There is a German translation of the Net of Faith (Cheltschizki 1970).

7 Quoted by (Wagner 1983, p. 70).

8 There was a great deal of variety among the Waldenses when it came to specific beliefs. In general, they were noted for their focus on the vernacular reading of Scripture, refusal to swear oaths (except to avoid execution), and denial of purgatory. Beyond that, some Waldensian groups embraced much Catholic practice and doctrine, while others called for a complete renunciation of the Catholic Church. (Lambert 2002, pp. 80-85, 175-89; Říčan 1992, p. 9).

9 (Müller 1922, p. 75; Brock 1957, p. 76). See the map of medieval heresy in (Lambert 2002, pp. 172-73).

10 (Müller 1922, pp. 129-32). On (Müller 1922, pp. 134-40), Müller discusses in great detail the historical problem of determining who the Waldensian elder was that consecrated Michael. Suffice it to say that the evidence is clear that it was not a Waldensian bishop in apostolic succession.

Quoted by (Müller 1922, p. 236).

Amedeo Molnár, “Brethren's Theology,” (Řičan 1992, p. 408).

14 (Crews 2018, pp. 1-46). Crews notes that fourteen of Luke's hymns appeared in the 1978 edition of the Czech Evangelical Church's hymnal.

15 Catechism, questions 18-22.

16 Catechism, questions 22-24; 32-34.

17 Catechism, question 75.

18 Quoted by (Müller 1922, p. 460).

19 (Pelikan and Hotchkiss 2003, p. 796). For the letter, see (Luther 1962, p. 151).

20 (David 2003, p. 57). David disputes the claim that there was a Neo-Utraquist party. "Despite much loose talk about Neo-Utraquism, no one has yet produced a Neo-Utraquist theological text, or even made a suggestion regarding along what lines a genuine dogmatic or liturgical synthesis of Utraquism and Lutheranism should proceed." (David 
2003, p. 230). I propose that the adoption of clerical marriage by the Utraquists does point in the direction of Neo-Utraquism.

21 Molnár, "The Theology of the Unity," in (Řičan 1992, p. 393).

22 (Greschat 1994, pp. 17-31), pointed to the correspondence between Bucer and the Brethren as evidence of "how flexible and versatile Bucer could be in developing his understanding of the proper relation between the spiritual and political exercise of authority and power in the community", p. 22.

23 Quoted from Bucer's commentary on John by (Wright 1994, p. 104). Bucer emphasized the role of the Holy Spirit more than the Brethren did, however (Stephens 1970, pp. 221-37).

24 (Pelikan and Hotchkiss 2003, p. 796; Kittelson 1975, pp. 158-59, 165-66). It is not accidental that one of the Reformed statements of faith acknowledged in the Ground of the Unity of the modern Moravian Church is the 1532 statement of the Synod of Bern, which was written by Capito.

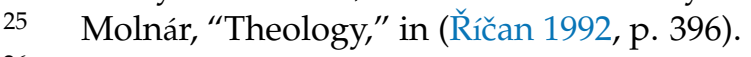

26 (Hammann 1994, pp. 129-43), looked at Bucer's idea of small Christian groups, but he did not mention the contacts with the Brethren who pioneered the type of community Bucer envisioned.

27 Molnár, "Theology," in (Říčan 1992, p. 396).

28 Herborn Academy is now the Theological Seminary for the Reformed Church of Hesse and Nassau.

\section{References}

Atwood, Craig D. 2007. Catechism of the Bohemian Brethren. Translated and edited from the 1523 German version. Journal of Moravian History 2: 91-118.

Atwood, Craig D. 2009. Theology of the Czech Brethren from Hus to Comenius. State College: University of Pennsylvania Press.

Augustine of Hippo. 1958. City of God. Garden City: Image Books.

Bainton, Roland H. 1978. Here I Stand: A Life of Martin Luther. Nashville: Abingdon Press.

Bittner, Konrad. 1954. Erasmus, Luther und die böhmischen Brüder. In Rastloses Schaffen. Edited by Heinz Seehase. Stuttgart: Kohlhammer, pp. 107-29.

Bozeman, Theodore Dwight. 1988. To Live Ancient Lives: The Primitivist Dimension in Puritanism. Chapel Hill: University of North Carolina Press.

Brady, Thomas A., Jr. 1993. The Earth is the Lord's and Our Homeland as Well': Martin Bucer and the Politics of Strasbourg. In Martin Bucer and 16th Century Europe. Edited by Christian Krieger and Marc Leinhard. Leiden and New York: E. J. Brill.

Brock, Peter. 1957. The Political and Social Doctrines of the Unity of Czech Brethren in the Fifteenth and Early Sixteenth Centuries. The Hague: Mouton.

Burnett, Amy Nelson. 1994. The Yoke of Christ: Martin Bucer and Christian Discipline. Kirksville: 16th Century Journal Publishers and Northeast Missouri State University.

Burnett, Amy Nelson. 2011. Karlstadt and the Origins of the Eucharistic Controversy: A Study in the Circulation of Idea. Oxford and New York: Oxford University Press.

Burnett, Amy Nelson. 2018. The Hussite Background to the Sixteenth-Century Eucharistic Controversy. The Bohemian Reformation and Religious Practice 11: 200-17.

Calvin, John. 1960. Institutes of the Christian Religion. In The Library of Christian Classics. Edited by John T. McNeill. Translated by Ford Lewis Battles. Philadelphia: Westminster, vols. 20-21.

Chelčický, Petr. 1964. 'On the Triple Division of Society' and 'On the Holy Church'. In Studies in Medieval and Renaissance History. Edited by Howard Kaminsky. vol. 1, Lincoln: University of Nebraska Press.

Cheltschizki, Peter. 1970. Das Netz des Glaubens. In Nikolaus Ludwig von Zinzendorf: Materialien und Dokumente, Reihe 1. Quellen und Darstellungen zur Geschichte der böhmischen Brüder-Unität. Edited by Band V. Amedeo Molnár. Translated by Carl Vogl. Hildesheim: Georg Olms.

Crews, C. Daniel. 2008. Faith, Love, Hope: A History of the Unitas Fratrum. Winston-Salem: Moravian Archives.

Crews, C. Daniel. 2018. Luke of Prague: Theologian of the Unity. Journal of Moravian History 18: 1-46. [CrossRef]

David, Zdeněk V. 1999. Utraquists, Lutherans, and the Bohemian Confession of 1575. Church History 68: 294-336. [CrossRef]

David, Zdeněk V. 2003. Finding the Middle Way: The Utraquists' Liberal Challenge to Rome and Luther. Washington, DC: Woodrow Wilson Center Press.

Fousek, Marianka S. 1961. The Perfectionism of the Early Unitas Fratrum. Church History 30: 396-413. [CrossRef]

Fousek, Marianka S. 1971. Spiritual Direction and Discipline: A Key to the Flowering and Decay of the 16th Century Unitas Fratrum. Archiv für Reformationsgeschichte 62: 207-24. [CrossRef]

Fudge, Thomas A. 2002. Luther and the 'Hussite' catechism of 1522. In Confessional Identity in East-Central Europe. Edited by Maria Craciun, Ovidiu Ghitta and Graeme Murdock. Aldershot: Ashgate, pp. 31-48.

Fudge, Thomas A. 2003. Concepts of Salvation in the Western Church to the Sixteenth Century. Communio Viatorum $45: 3$.

Fudge, Thomas A. 2014. Heresy and Hussites in Late Medieval Europe. Farnham: Ashgate-Variorum.

Fudge, Thomas A. 2016. Medieval Religion and Its Anxieties: History and Mystery in the Other Middle Ages. New York: Palgrave MacMillan.

Greschat, Martin. 1990. Martin Bucer. Ein Reformator und seine Zeit 1491-1551. Munich: Verlag CH Beck. 
Greschat, Martin. 1994. The relation between church and civil community in Bucer's reforming work. In Martin Bucer: Reforming Church and Community. Edited by David F. Wright. New York: Cambridge University Press, pp. 17-31.

Greschat, Martin. 2004. Martin Bucer: A Reformer and His Times. Translated by Stephen E. Buckwalter. Louisville: Westminster John Knox Press.

Haberkern, Philip. 2016. Patron Saint and Prophet: Jan Hus in the Bohemian and German Reformation. Oxford: Oxford University Press.

Haberkern, Philip. 2017. Luther's Understanding of Earlier Reformers. In The Oxford Encyclopedia of Martin Luther. Edited by Derek Nelson and Paul Hinlicky. Oxford: Oxford University Press. Available online: https:// oxfordre.com/religion/view/10.1093/ acrefore/9780199340378.001.0001/acrefore-9780199340378-e-281 (accessed on 15 March 2021).

Haberkern, Phillip. 2018. Was the Bohemian Reformation a Failure? The Bohemian Reformation and Religious Practice 11: $217-37$. Available online: http:/ / www.brrp.org/vol11contents.html (accessed on 15 March 2021).

Haberkern, Phillip. 2020. The Bohemian Reformation and 'The' Reformation: Hussites and Protestants in Early Modern Europe. In $A$ Companion to the Hussites in the Series Brill's Companions to the Christian Tradition. Edited by Michael van Dussen and Paul Soukup. Leiden: Brill, vol. 90, pp. 403-38.

Hägglund, Bengt. 1968. History of Theology. Translated by Gene J. Lund. St. Louis: Concordia.

Halama, Ota. 2020. The Unity of Brethren (1458-1496). In A Companion to the Hussites in the series Brill's Companions to the Christian Tradition. Edited by Michael van Dussen and Paul Soukup. Leiden: Brill, vol. 90, pp. 371-402.

Hammann, Gottfried. 1994. Ecclesiological motifs behind the creation of the 'Christlichen Gemeinschaften'. In Martin Bucer: Reforming Church and Community. Edited by David F. Wright. New York: Cambridge University Press, pp. 129-43.

Hazlett, Ian. 1994. Eucharistic communion: Impulses and directions in Martin Bucer's thought. In Martin Bucer: Reforming Church and Community. Edited by David. F. Wright. New York: Cambridge University Press, pp. 72-82.

Horníčková, Kateřina, and Michal Šroněk, eds. 2016. From Hus to Luther. Turnhout: Brepols.

Iwánczak, Wojciech. 1997. Between Pacifism and Anarchy: Peter Chelcicky Teaching about Society: Hussite Views on the Organisation of Christian Society. Journal of Medieval History 23: 271-83. [CrossRef]

Kalivoda, Robert. 2014. The Social Outcome of the Hussite Revolution. In Between Lipany and White Mountain: Essays in Late Medieval and Early Modern Bohemian History in Modern Czech Scholarship. Edited by James R. Palmitessa. Leiden: Brill, pp. 43-62.

Kittelson, James. 1975. Wolfgang Capito: From Humanist to Reformer in the Series Studies in Medieval and Reformation Thought. Leiden: Brill.

Kittelson, James. 1994. Martin Bucer and the ministry of the church. In Martin Bucer: Reforming Church and Community. Edited by David F. Wright. New York: Cambridge University Press, pp. 83-94.

Lambert, Malcolm. 2002. Medieval Heresy: Popular Movements from the Gregorian Reform to the Reformation, 3rd ed. Oxford: Blackwell.

Larangé, Daniel S. 2008. La Parole de Dieu en Bohême et Moravie. La tradition de la prédication dans l'Unité des Frères de Jan Hus à Jan Amos Comenius. Paris: L'Harmattan.

Lohse, Bernhard. 1965. Luther und Huß. Luther, Zeitschrift der Luthergesellschaft 36: 108-22.

Luther, Martin. 1962. Temporal Authority: To What Extent Should it be Obeyed (1523). In Luther's Works. Edited by Jaroslav Pelikan, Hartmut Lehman, Joel W. Lundeen, Christopher Boyd Brown, Benjamin T. G. Mayes and James L. Langebartels. Translated by J. J. Schindel, and Walther I. Brandt. Philadelphia: Fortress Press, pp. 75-128.

McKee, Elsie. 1994. Reforming Popular Piety in 16th century Strasbourg. Studies in Reformed Theology and History 2: 1-82.

McKee, Elsie. 1998. Katherina Schütz Zell. Leiden: Brill.

Molnár, Amedeo. 1973. The Czech Confession of 1575. Communio Viatorum 16: 241-47.

Molnár, Amedeo. 1983. Luthers Beziehungen zu den Böhmischen Brüdern. In Leben und Werk Martin Luthers von 1526 bis 1546. Edited by Helmar Junghans. Göttingen: Vandenhoeck \& Ruprecht, vol. 1, pp. 627-39.

Molnár, Amedeo. 1987. Erasmus und das Hussitentum. Communio Viatorum 30: 185-97.

Müller, Joseph. 1887. Die Deutschen Katechismen der böhmischen Brüder, Kritische Textausgabe mit kirchen- und dogmengeschichtlichen Untersuchungen und einer Abhandlund über das Schulwesen der böhmischen Brüder. In N. L. von Zinzendorf Materialien und Dokumente. Edited by Erich Beyreuther, Gerhard Meyer and Amedeo Molnár. Hildesheim: Georg Olms, Berlin: Hofman, vol. 1.

Müller, Joseph. 1922. Geschichte der böhmischen Brüder. Herrnhut: Verlag der Missionsbuchhandlung.

Odložilîk, Otakar. 1965. The Hussite King: Bohemia in European Affairs, 1440-1471. New Brunswick: Rutgers University Press.

Ozment, Steven. 1992. Protestants: The Birth of a Revolution. New York: Doubleday.

Palmitessa, James R., ed. 2014. Between Lipany and White Mountain: Essays in Late Medieval and Early Modern Bohemian History in Modern Czech Scholarship. Leiden: Brill.

Pelikan, Jaroslav, and Valerie Hotchkiss. 2003. Creeds and Confessions of Faith in the Christian Tradition. New Haven: Yale University Press.

Pelikan, Jaroslav. 1983. Reformation of Church and Dogma (1300-1700). Vol. 4 of The Christian Tradition: A History of the Development of Doctrine. Chicago: University of Chicago Press.

Peschke, Erhar. 1981. Kirche und Welt in der Theologie der Böhmischen Brüder Vom Mittelalter zur Reformation. Berlin: Evangelische Verlagsanstalt. Phillips, Margaret. 1949. Erasmus and the Northern Renaissance. New York: Macmillan.

Říčan, Rudolf. 1992. The History of the Unity of the Brethren: A Protestant Hussite Church in Bohemia and Moravia. Translated by C. Daniel Crews. Bethlehem: Moravian Church in America.

Scribner, Robert W. 1986. Incombustible Luther: The Image of the Reformer in Early Modern Germany. Past E Present 110: 38-68.

Scribner, Robert W. 1994. For the Sake of Simple Folks: Popular Propaganda for the German Reformation, 2nd ed. Oxford: Clarendon Press. 
Selderhuis, Herman J. 1999. Marriage and Divorce in the Thought of Martin Bucer. Translated by John Vriend, and Lyle D. Bierma. Kirksville: Thomas Jefferson University Press.

Spinka, Matthew. 1943. Peter Chelcicky the Spiritual Father of the Unitas Fratrum. Church History 12: 271-91. [CrossRef]

Stephens, William Peter. 1970. The Holy Spirit in the Theology of Martin Bucer. Cambridge: Cambridge University Press.

Štrupl, Miloš. 1964. Confessional Theology of the Unitas Fratrum. Church History 33: 279-93. [CrossRef]

Thompson, Nicholas. 2005. Eucharistic Sacrifice and Patristic Tradition in the Theology of Martin Bucer 1534-1546. Leiden: Brill.

Thomson, S. Harrison. 1953. Luther and Bohemia. Archiv für Reformationsgeschichte 44: 160-81. [CrossRef]

Wagner, Murray. 1983. Peter Chelčicky: A Radical Separatist in Hussite Bohemia. Scottdale: Herald Press.

Wright, David F., ed. 1994. Martin Bucer: Reforming Church and Community. New York: Cambridge University Press.

Zeman, Jarold Knox. 1969. The Anabaptists and the Czech Brethren in Moravia 1526-1628. The Hague and Paris: Mouton. 